TECHNICAL NOTE

D-1543

\title{
USE OF A SEALED SILVER-CADMIUM BATTERY ON EXPLORER XII
}

\author{
T. J. Hennigan and A. O. Apelt \\ Goddard Space Flight Center \\ Greenbelt, Maryland
}

NATIONAL AERONAUTICS AND SPACE ADMINISTRATION 


\title{
USE OF A SEALED SILVER-CADMIUM BATTERY ON EXPLORER XII
}

\author{
by \\ T. J. Hennigan and A. O. Apelt \\ Goddard Space Flight Center
}

\begin{abstract}
SUMMARY
Since silver-cadmium cells may be constructed entirely free of magnetic materials, a secondary silver-cadmium battery was used on Explorer XII satellite, launched in 1961 to study radiation and magnetic fields. A program has been carried out at Goddard Space Flight Center to determine the feasibility of using the battery in this space application. The operation of the power system on Explorer XII is outlined and cycling data, telemetered from the satellite, are presented. The first application of a silver-cadmium battery on a satellite was very satisfactory; in flight, no deterioration of the battery power supply was observed.
\end{abstract}




\section{CONTENTS}

Summary ....................... i

INTRODUCTION. ...................... 1

EXPLORER XII APPLICATION ................ 1

BATTERY CHARACTERISTICS ............... 3

CONCLUSION $\ldots \ldots \ldots \ldots \ldots \ldots \ldots \ldots \ldots$ 


\title{
USE OF A SEALED SILVER-CADMIUM BATTERY ON EXPLORER XII
}

\author{
by \\ T. J. Hennigan and A. O. Apelt \\ Goddard Space Flight Center
}

\section{INTRODUCTION}

The initial interest in the silver-cadmium couple arose during the design phase of Explorer XII. The primary purpose of this satellite was to measure radiation and magnetic fields in space. Because of its magnetometer, the satellite required components on board with minimum magnetic effects. At that time, the possibility of a nonmagnetic $\mathrm{Ag}-\mathrm{Cd}$ battery was known, but little information was available which would warrant the operation of this system for a year at 1 cycle per $26.5 \mathrm{hr}$, the orbital time of the satellite.

\section{EXPLORER XII APPLICATION}

During the first half of 1961, a program carried out at Goddard Space Flight Center (GSFC) to investigate the various parameters of the sealed $\mathrm{Ag}-\mathrm{Cd}$ system resulted in the design of the battery shown in Figure 1. It consisted of thirteen 5-amp-hr Yardney Ag-Cd cells connected in series and potted in Epon 834. The outer case was aluminum, giving a total battery weight of 6.3 pounds. A current sensor was included to provide a readout in flight of the charge and discharge currents, and calibrated thermistors were used to monitor battery temperature. Charge and discharge voltages were telemetered. The duty cycle during flight was approximately a 1 amp discharge for 30 minutes, followed by a 26-hr charge from the solar array. A block diagram of the Explorer XII power system is shown in Figure 2.

The solar array was capable of delivering power at $16 \mathrm{w}$ (nominal); the voltage regulator maintained a 19.6-v input across the battery and load during sunlight. As the battery became charged, the excess current was dumped through the regulator, thereby regulating the solar array near its maximum power point. The battery was capable of operating the payload throughout the temperature range $-10^{\circ} \mathrm{C}$ to $+50^{\circ} \mathrm{C}$. During the orbital lifetime the actual battery temperature ranged from $+10^{\circ} \mathrm{C}$ to $+28^{\circ} \mathrm{C}$.

The discharge voltage of the battery varied from 16 to $13 \mathrm{v}$ at the required payload power ratio of $14 \mathrm{w}$. During flight, the battery discharged about 10 percent of its nominal 5-amp-hr capacity. 


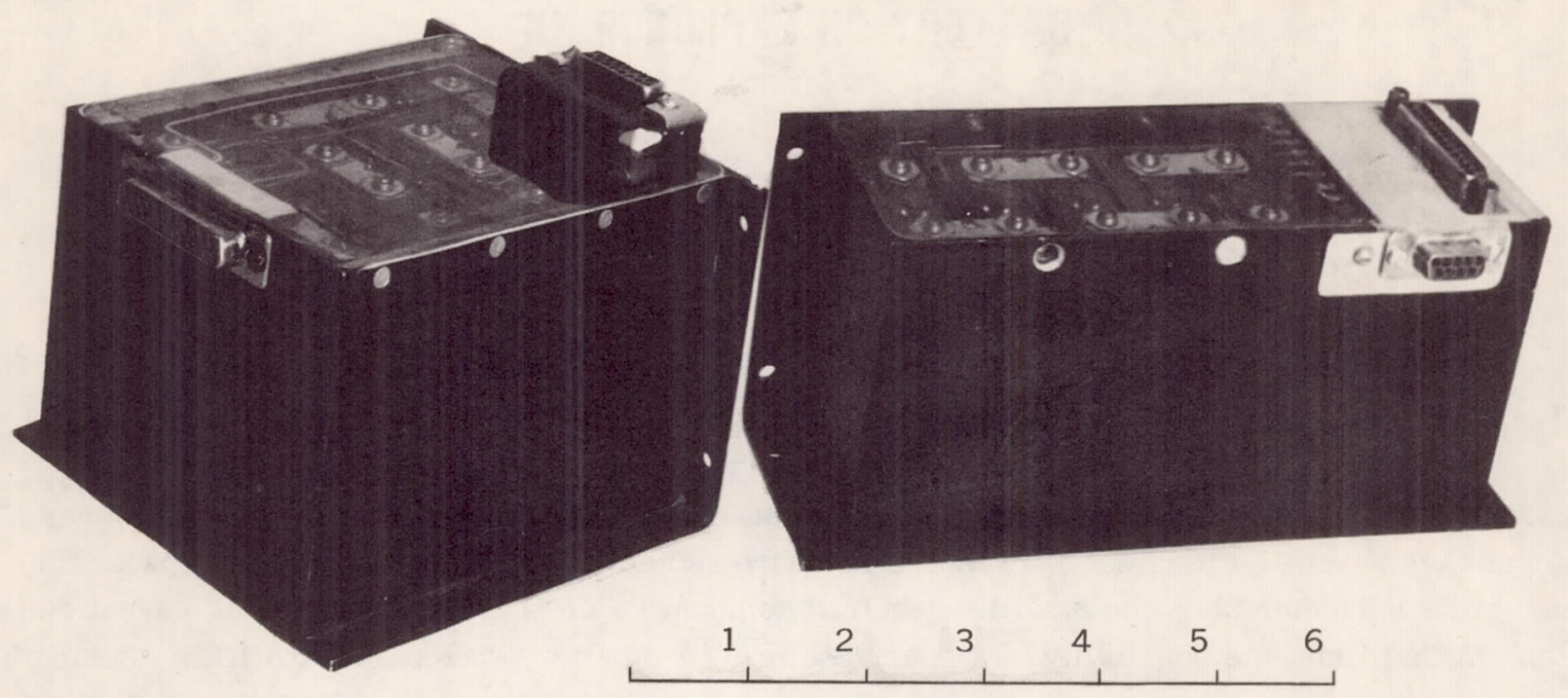

Figure 1-Explorer XII silver-cadmium batteries

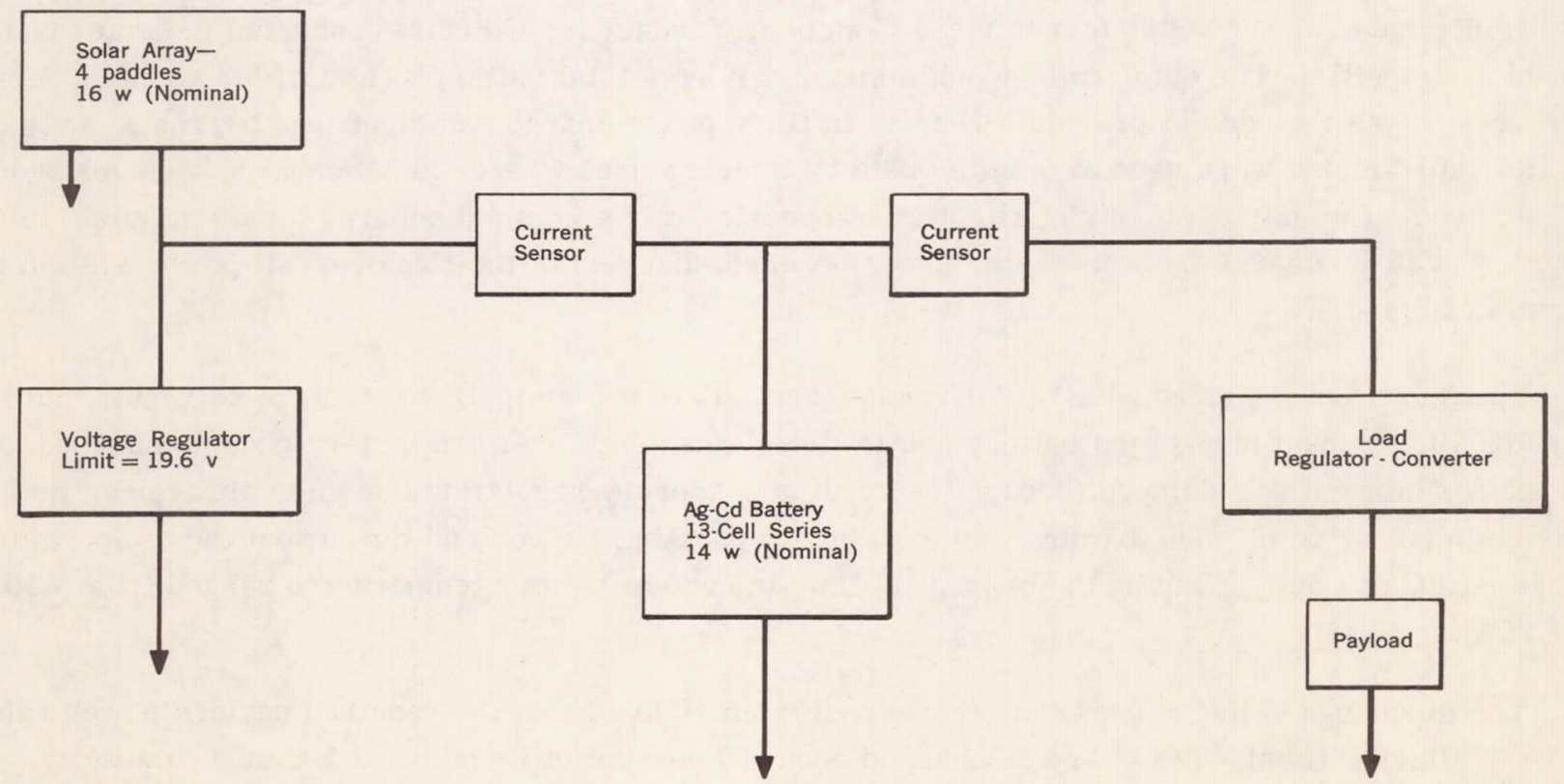

Figure 2-Explorer XII power supply 
A circuit on board sensed the battery discharge voltage, and if the battery showed a low state of charge the load was taken off the line for 8 hours to allow the solar array to recharge the battery. The cutoff was at $12 \mathrm{v}$, over the temperature range $-10^{\circ} \mathrm{C}$ to $+50^{\circ} \mathrm{C}$.

Typical charge characteristics, after a discharge during shadow time, are shown in Figure 3. Note that the amp-hr capacity removed during shadow was replaced in about 6 hours, and at end of charge, the current had decreased to less than $2 \mathrm{ma}$. It has been found that, during this type of orbit, the battery would operate at an amp-hr efficiency of 97 percent or better.

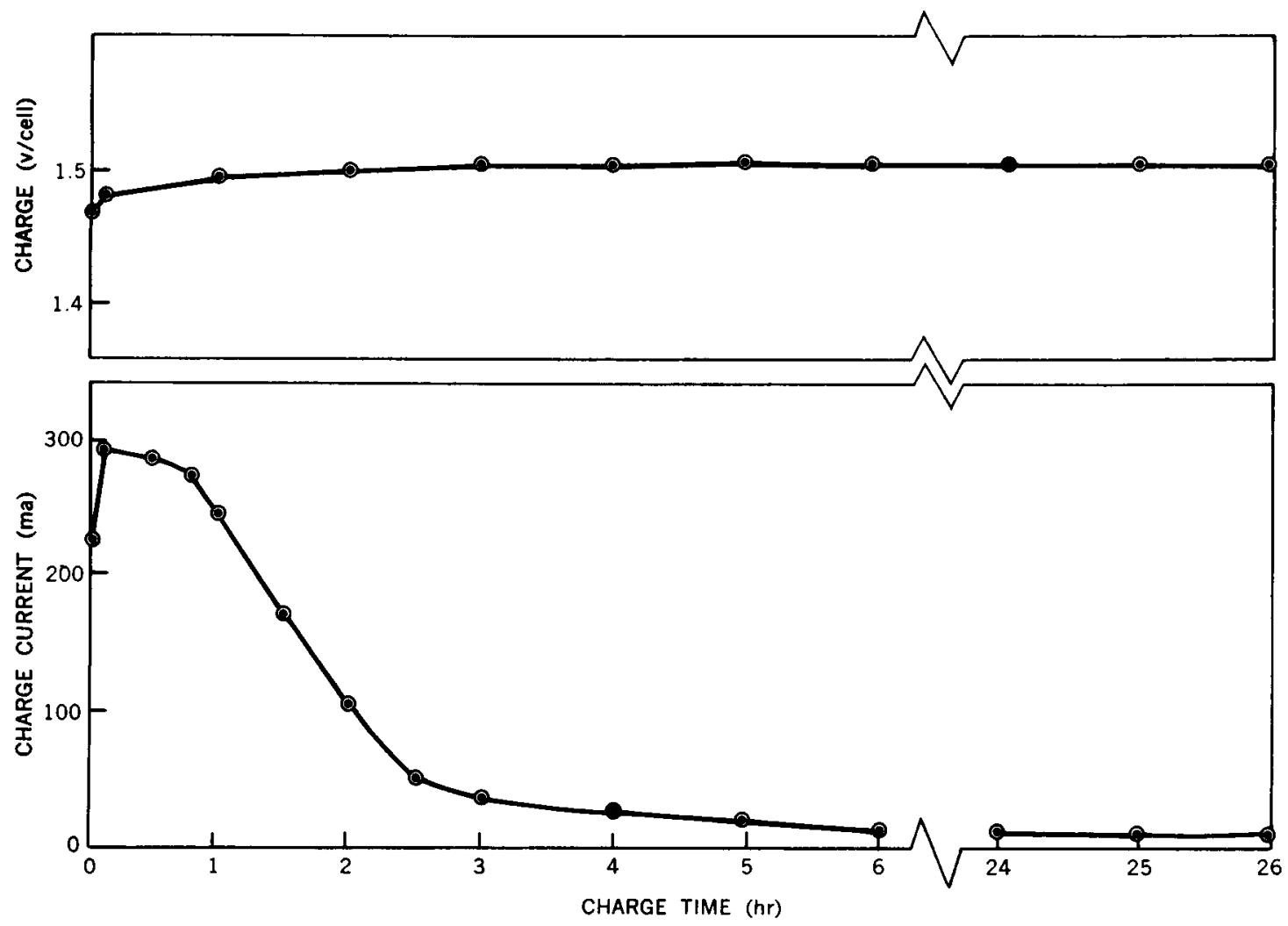

Figure 3-Explorer XII silver Ag-Cd battery typical charge characteristics after discharge in earth's shadow

\section{BATTERY CHARACTERISTICS}

As was mentioned before, a program has been carried out at GSFC to determine the parameters of the sealed $\mathrm{Ag}-\mathrm{Cd}$ system for use on Explorer XII. The major points of this investigation are:

Optimum Charging Voltage-For the type of orbit and depth of battery discharge of Explorer XII, a constant potential charge voltage of $1.50 \mathrm{v} /$ cell was very satisfactory. Not only was this voltage capable of maintaining cell capacity but also, at this voltage, gassing is negligible. Since the solar array is inherently a current limiting device, the actual charging, either simulated or in flight, was of the modified constant-potential type with $1.50 \mathrm{v} /$ cell maintained at the end of charge and during trickle charge. 
Discharge Characteristics - The discharge characteristics of the $\mathrm{Ag}-\mathrm{Cd}$ couple were investigated over the temperature range $-10^{\circ} \mathrm{C}$ to $+50^{\circ} \mathrm{C}$. The range of voltage at the 6 -hour rate, over this temperature range, is from $1.27 \mathrm{v} /$ cell at the beginning of discharge to $1.05 \mathrm{v} /$ cell on the second or AgO plateau. A typical discharge of a Ag-Cd cell at room temperature is shown in curve A of Figure 4. About 25 percent of the capacity is removed at the AgO level, while the remainder is discharged at the $\mathrm{Ag}_{2} \mathrm{O}$ level. A curious phenomenon occurs when the $\mathrm{Ag}-\mathrm{Cd}$ couple is either cycled with long trickle charge periods, or trickle charged only for long periods of time. As shown in curve B of Figure 4, the peroxide portion of the curve is depressed, and all the capacity can be recovered at the monoxide level. Usually, an increase in capacity is observed. Nominal 5-amp-hr cells can be cycled or trickle charged so that on discharge, a capacity in excess of $7 \mathrm{amp}-\mathrm{hr}$ is realized at the monoxide level. (Note the excellent voltage regulation.) This phenomenon is under further study.

Effects of Nonuniformity in a Series String, Especially at the End of Charge-During the evaluation program, considerable data were taken to determine the degree of nonuniformity or unbalance of cells in series at the end of charge. Even though the Yardney Electric Company was able to select cells having uniform charge characteristics, occasionally a few cells in a series string would unbalance. Some cells have shown end-of-charge voltages as high as $1.8 \mathrm{v}$; naturally, gassing occurs, but fortunately, the end-of-charge current is on the order of 2 ma. An investigation was carried out on single cells to determine the pressure variation of the 5 -amp-hr cells at voltages greater than 1.50, and at low current levels. Typical data are shown in Figure 5. Maximum pressures of the order of 50 psig were observed, but after attaining this value, the gas pressure would either drop off sharply or, in some cases, decrease gradually with no further pressure rise even at a high charge voltage. This effect is being studied further.

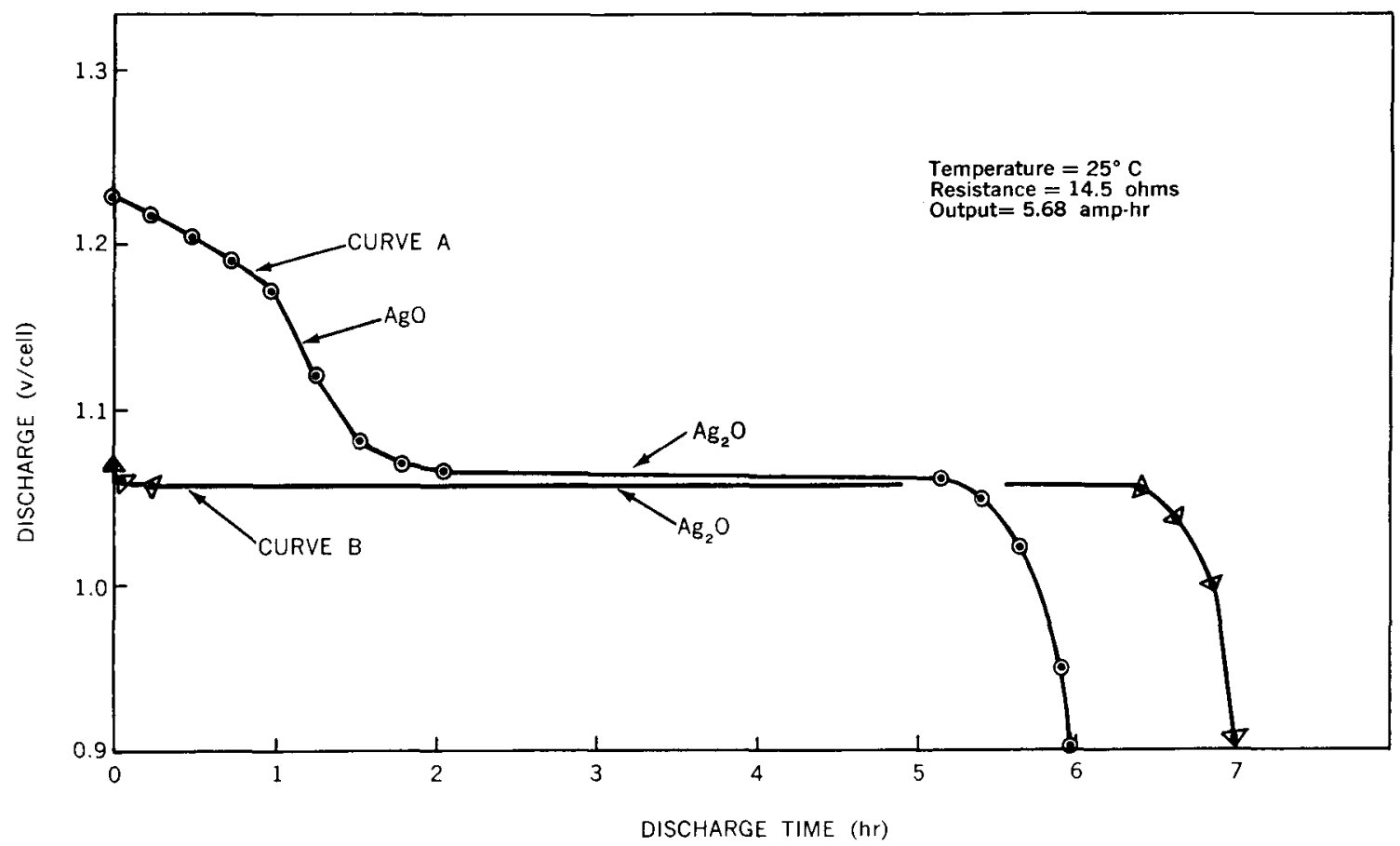

Figure 4-Explorer XII Ag-Cd battery typical constant resistance discharge 


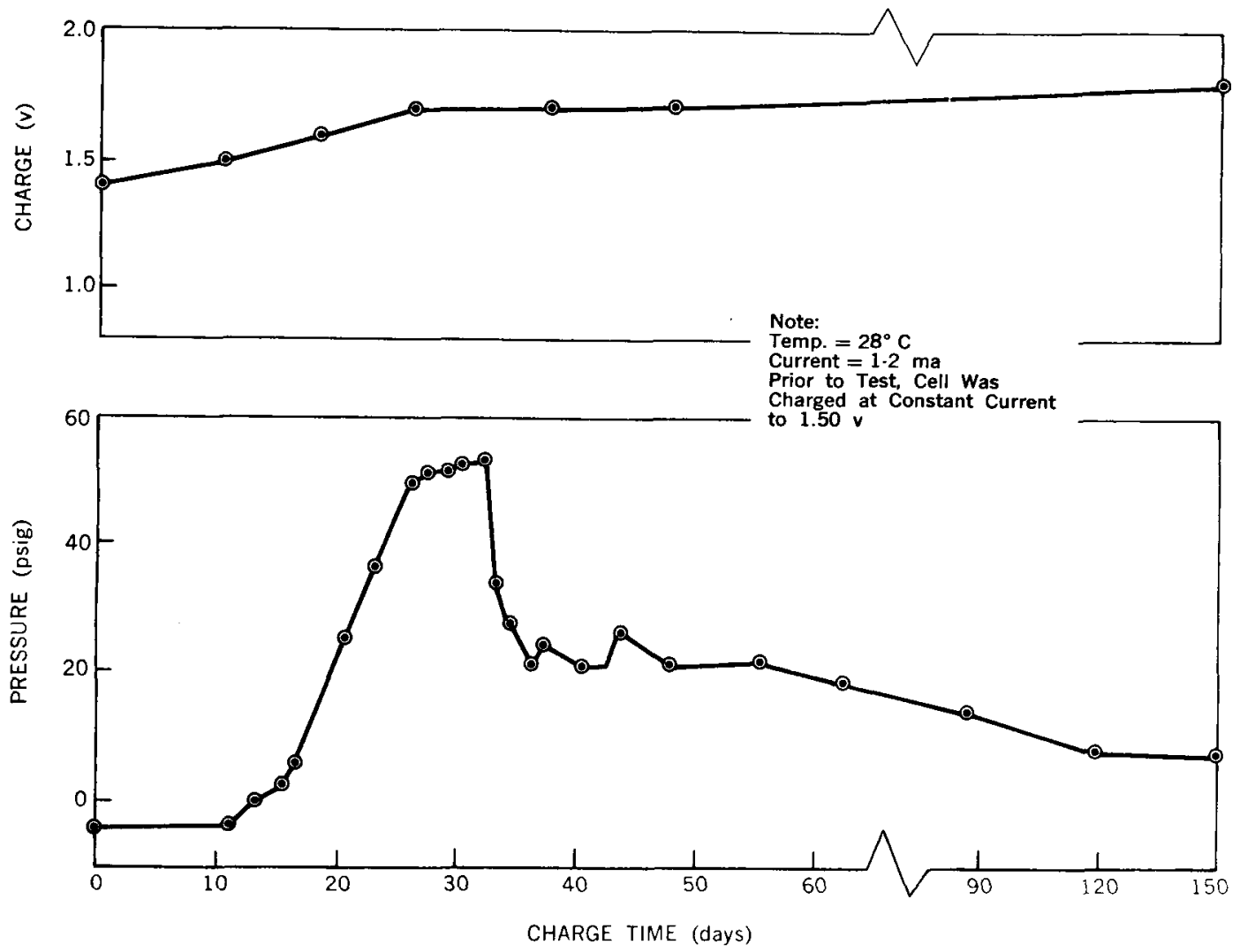

Figure 5-Variation of internal pressure of a sealed $\mathrm{Ag}-\mathrm{Cd}$ cell continuously charged at $\mathrm{E}>1.50 \mathrm{v}$

Thermal Characteristics Resulting from Charge or Discharge in Vacuum $\left(10^{-5} \mathrm{~mm} \mathrm{Hg}\right)-$ During a 10 percent depth of discharge of an Explorer XII-type battery, at $25^{\circ} \mathrm{C}$ and in a vacuum of $10^{-5} \mathrm{~mm}$ $\mathrm{Hg}$, the temperature of the battery on discharge rose less than $2^{\circ} \mathrm{C}$; there was no temperature rise during a charging mode of the type used on Explorer XII.

Leak Rates of Epoxy Encapsulated Batteries-One phase of the evaluation program was to determine the helium leak rates of epoxy encapsulated batteries. The leak rates of single cells (at S.T.P.) were less than $2 \times 10^{-6} \mathrm{~cm}^{3} / \mathrm{sec}$, while the leak rates of 13 -cell batteries were less than $3 \times 10^{-6}$ $\mathrm{cm}^{3} / \mathrm{sec}$. Neither vibration nor temperature cycling had any damaging effect on the seal.

Ampere-hour and Watt-hour Efficiencies at Room Temperature-As has been mentioned, the amp-hr efficiency of the Ag-Cd system during the orbital cycle of Explorer XII was 97 percent. The $\mathrm{w}$-hr efficiency of the battery, depending upon the degree of depression of the peroxide level, was between 80 and 68 percent, and the energy per unit weight of the battery was $13.0 \mathrm{w}-\mathrm{hr} / \mathrm{lb}$.

\section{CONCLUSION}

The first application of the $\mathrm{Ag}-\mathrm{Cd}$ system on a satellite was very satisfactory. During the 112 day lifetime of Explorer XII, telemetered data showed no deterioration of the battery power supply. 
The amp-hr efficiency of the system was 97 percent or better, and with no overcharge required, the battery did not present a thermal problem. Laboratory tests showed the epoxy seal to be satisfactory, and since the battery showed no deterioration in space, the epoxy seal appears to be a reliable sealing technique in space applications. At the present time, three more satellites are scheduled to use the $\mathrm{Ag}-\mathrm{Cd}$ system as a battery power supply. 